Eletronic Magazine: Time - Techinique - Territorry, V.6, N.1 (2015), 23:43 ISSN: 2177-4366

DOI: https://doi.org/10.26512/ciga.v6i1.20919

\title{
CONFLICTS IN INDIGENOUS TERRITORIES: THE OVERLAYS BETWEEN INDIGENOUS LANDS AND PROTECTED CONSERVATION UNIT AREAS \\ Vinícius Galvão Zanatto
}

\author{
Geographer - graduated at the University of Brasilia \\ Email: vini.galvaozanatto@gmail.com
}

\begin{abstract}
The indigenous communities have been marginalized from the beginning of the construction of the Brazilian national society, even with the federal constitution defining indigenous rights that guarantees them not to be respected. These populations were ignored during the construction of Brazilian environmental policy, accordingly this paper seeks to demonstrate the importance of indigenous peoples to build an efficient and fair environmental policy. It aims also geographically explain why historically not resolve conflicts involving indigenous reserves in Brazil, especially conflicts of territorial overlap with Conservation Units. I assume that indigenous peoples have the right to remain in their territories, but also are critical to maintaining the existing biodiversity in the country, which is the result set of knowledge historically constructed in the territory. Discussions about the use and conservation of natural resources are extremely important today, but we should not discuss the right of indigenous people to remain in their territories, because if we see a great diversity of species in these places is because such people are there. The territorial conflicts of overlaps only mask the real problem is that the model of development stimulated by the state.
\end{abstract}

KEYWORDS: Traditional Territory, Indigenous Reserve, Conservation Unit, Territorial Overlay

RESUMO: As comunidades indígenas foram marginalizadas desde o princípio da construção da sociedade nacional brasileira, mesmo com a Constituição Federal definindo os direitos indígenas essa não lhes garante que sejam respeitados. Tais populações foram ignoradas durante a construção da política ambiental brasileira, nesse sentido o presente artigo visa demonstrar a importância das populações indígenas para a construção de uma política ambiental eficiente e justa. Tem como objetivo também explicar geograficamente o porquê historicamente não se resolvem os conflitos envolvendo Terras indígenas no Brasil, em especial os conflitos de sobreposições territoriais com Unidades de Conservação. Parto do 
princípio de que as populações indígenas tem direito de permanecer em seus territórios, mas além disso são fundamentais para a manutenção da biodiversidade existente no país, sendo esta o resultado conjunto de conhecimentos historicamente construídos no território. As discussões sobre a utilização e conservação dos recursos naturais são de extrema importância nos dias atuais, porém não deveríamos discutir o direito das populações indígenas em permanecer em seus territórios, pois se vemos uma grande diversidade de espécies nesses locais é porque tais populações estão lá. Os conflitos de sobreposições territoriais só mascaram o verdadeiro problema que está no modelo de desenvolvimento estimulado pelo Estado.

PALAVRAS-CHAVE: Território Tradicional, Terra Indígena, Unidade de Conservação, Sobreposição Territorial.

RESUMEN: Las comunidades indígenas han sido marginadas desde el inicio de la construcción de la sociedad brasileña, incluso con la Constitución Federal que define los derechos indígenas que no garantizan que sean respetados. Estas poblaciones fueron ignoradas durante la construcción de la política ambiental brasileña, en este sentido, el presente artículo tiene como objetivo demostrar la importancia de los pueblos indígenas para construir una política ambiental eficiente y justa. También tiene como objetivo a explicar geograficamente por qué históricamente no resuelve los conflictos relacionados con las Tierras Indígenas en Brasil, sobre todo los conflictos de superposición territorial con lãs Unidades de Conservación. Asumo que los pueblos indígenas tienen el derecho a permanecer en su territorio, sino que también son fundamentales para mantener la biodiversidad existente en el país, que es el conjunto de resultados del conocimiento construido históricamente en el territorio. Debates sobre el uso y conservación de los recursos naturales son muy importantes hoy en día, pero no debemos discutir el derecho de los indígenas a permanecer en su territorio, ya que si vemos una gran diversidad de especies en estos lugares es porque esas personas están ahí. Conflictos de superposición territorial sólo enmascaran el verdadero problema es que el modelo de desarrollo estimulado por el Estado.

PALABRAS CLAVE: Territorio Tradicional, Tierra Indígena, Unidad de Conservación, Superposición Territorial. 


\section{INTRODUCTION}

Working with indigenous issues is first of all to acknowledge the existence of different ways of life, is (re) learn the cultural and social diversity of the country, it is to interact with ancestral knowledge and the right to exercise this knowledge through the ages.

With the democratization of the country there has been a certain advance when it comes to protection and recognition of indigenous rights in the country, and through the Constitution of 1988 the rights to the lands they traditionally occupy were recognized.

The construction of the Brazilian society is given based on an unequal dispute between societies that historically occupied the region and those who declared themselves owners due to the fact of having "discovered" a land of "nobody" it is in the context of ethnocide and subjugation that occurs the assimilation system of indigenous peoples to the Western civilization (LIMA, 2010).

Even with the Brazilian Constitution defining indigenous rights, this does not give them guarantees that they are respected and treated without violence, what happens actually, is the opposite, we can observe that governments turn a blind eye to cases of violence undertaken towards indigenous people and excludes them as political actors.

There is a lack of knowledge from the side of the national society related to (education, health, prison, etc.) indigenous population, but when it comes to indigenous lands and their territories the situation turns into visibility and interest (LIMA, 2010).

Lima (2010) states that the natural resources in indigenous territories coexist with different economic interests, which generates a context of constant struggle for territory even though this is already legally supported.

This article is part of research made by the Department of Geography from the University of Brasilia, in the fields of Practice and Research I and II, along with the Applied Cartography and Geographic Information Center - CIGA, supervised by Professor Dr. Rafael Sanzio Araújo dos Anjos, which resulted in the preparation of a monograph on conflicts involving institutions within indigenous territories, specifically the work focused on the territorial overlap at the Araguaia National Park with indigenous lands of Ilha do Bananal region, located southwest of the state of Tocantins ${ }^{1}$.

This article aims to geographically explain why historically unresolved conflicts involving indigenous lands in Brazil, especially the conflicts of territorial overlap with 
conservation unit areas and also demonstrate the importance of Indigenous Lands in building an efficient and fair environmental policy.

The research starts from the premise that indigenous peoples have the right to remain in their territories, but moreover they are fundamental for the maintenance of the existing biodiversity in the country, being the joint result of historically built knowledge on the territory.

${ }^{1}$ ZANATTO, Vinícius Galvão, Conflitos institucionais em territórios indígenas: o caso das terras indígenas da Ilha do Bananal e o Parque Nacional do Araguaia - TO, 2014, Universidade de Brasília.

\section{TERRITORY AND TRADITIONAL TERRITORIALITY}

Saquet (2004) states that it is necessary to overcome the conception of territory only as a state instrument of action, politics, or as merely cultural identity. To Saquet, visions would be complementary. This view corroborates with what Haesbaert (2004) states: "The territory has to be seen from multiple power relations, from the most concrete, the economic and political relations, and to the most subjective power concerning cultural and existential issues".

This multiple vision must be used because of the great diversity of territories and existent territorialities often overlap each other and are not able to exclude or isolate from each other, there are among the most diverse areas inevitable interaction.

To Santos territory is:

The ground along with the population, that is, an identity, the fact and the feeling of belonging to what belongs to us. And adds, still it is the basis of work, residence, the material and spiritual exchanges and life, on which it influences. (SANTOS, 2002, p.96).

We can understand from the above quote that the territory is the basis of identity constructions, of the everyday, of the living, it is in the territory that life manifests itself, identity is fundamentally territorial, built upon the social relations of the community (VILELA, 2013).

To Claval (1995), the territory plays a central role in the construction of collective identities, as it is the common presence of the material basis of common existence and provides part of the essential resources to the existence of each one, the territory is shared, formed by different places loaded with meanings accessible to all (pilgrimages, shrines, historical monuments, past generations lived in the territory and that is where their bodies lie). 
The presence of certain traditional community in the geographic space presents itself from the use of the territory (VILELA, 2013).

The distinction of a traditional community is related to actions and individual appropriation actions of land resources, such as the dependence on natural resources available in the territory, which enables the development of managements of these resources. Orality is also closely related to the construction of certain traditional social group because it spreads how the territory should be used, and maintains traditional practices through the generations (VILELA, 2013).

Little (2002) analyzes the territory from the conception of territoriality which for him is: "The collective effort of a social group to occupy, use, control and identify with a specific portion of their biophysical environment, converting it that way on its territory."

We have to take into account that the effort of a social group is different from other groups, thus territoriality takes multiple features, which for Little (2002), will produce a wide range of areas, with socio-cultural specificities.

Thus to understand a traditional indigenous community, we have to analyze the different meanings that this population gives to the territory, how it identifies itself with the environment they live on, upon a different logic from that established by western society.

The traditional way of life is established in the territory, and dependent on it is the main factor that characterizes a population like traditional, self-identification. Only the possibility of distinguishing certain traditional practices if these are rooted within the population and comes out concretely in geographic space (VILELA, 2013).

By the present singularities in indigenous territories and multiple existing territorialities, a vision becomes necessary which take complex spatial arrangements into account, so that they can articulate the relationship between society and nature (Silva and Nogueira, 2010).

\section{INDIGENOUS LAND DOES NOT MEAN INDIAN TERRITORY}

Indigenous lands represent a legal category of organization of the space, and only acquire effective expression after its delimitation and demarcation (BECKER, 2004).

According to Diegues and Arruda (2001) traditional territories, that include indigenous territories, are discontinuous and marked by an apparent emptiness. That is because the use of territory made by these populations is different, there being fishing and hunting areas used only at certain times of the year, and sacred areas that are not properly used for resources, but have a close and historic connection with society.

Eletronic Magazine: Time - Techinique - Territorry, V.6, N.1 (2015), 23:43 ISSN: 2177-4366 
Indigenous Lands are part of indigenous territories, they are defined based on the territoriality of the population, but are not constituted as being the territory in its totality.

Gallois (2004) distinguishes Indigenous Land and Indigenous Territory referring the first subject to a political and legal process governed by the State, and the second to the construction and living of a social group with their territorial base.

The Constitution of 1988 is considered an advance when it comes to indigenous related issues recognizing the lands traditionally occupied by them defining them as:

$1^{\circ}$ Traditionally occupied lands by Indians are those on which they live on a permanent basis, those used for their productive activities, those indispensable to the preservation of environmental resources necessary for their well-being and those necessary for their physical and cultural reproduction, according to their uses, customs and traditions (BRASIL, 1988).

In addition to defining what lands traditionally occupied are, the Constitution of 1988 deals with the use and possession of traditionally occupied lands by Indians and defines: " $2^{\text {nd }}$ Traditionally occupied lands by Indians are destined for their permanent possession, being up to them the exclusive use of the riches in the soil, existing rivers and the lakes therein. "

The Constitution also states that their lands are inalienable and unavailable, and the rights granted to it are imprescriptible.

Thus we cannot analyze the relations involving conflicts associated to indigenous peoples, without first making an analysis of what and how the territories are constituted.

There are currently 522 Indigenous Lands, 115 in the study phase and 32 Indigenous Reserves composing a total of 673 indigenous lands in various stages of demarcation.

Table 1: demarcation phase, total and surface of indigenous lands in Brazil

\begin{tabular}{|l|c|c|}
\hline Demarcation Phase & Total of Indigenous Lands & Surface (ha) \\
\hline Under study & 115 & $3.697,0207$ \\
\hline Delimited & 32 & $2.058 .022,0000$ \\
\hline Declarared & 52 & $2.767 .211,9233$ \\
\hline Approved & 16 & $1.747 .789,5298$ \\
\hline Regularized & 422 & $103.194529,9552$ \\
\hline Indigenous Reserve & 36 & $46.657,5830$ \\
\hline Total & 673 & $109.817 .908,0120$ \\
\hline
\end{tabular}

Source: Sistema Indigenista de Informações, August, 2014 (FUNAI) / Elaborated by: Vinícius Galvão Zanatto. August, 2014.

The indigenous lands "under study", do not have their definite limits yet and are in the process of planning and complimentary studies, the "delimited" Indigenous Lands have their boundaries and are under contesting analysis also by the Ministry of Justice contesting analysis, concerning the " declared " indigenous lands, thesye have physical demarcation, are 
either under approval process, or demarcations being planned, the "approved " Indigenous Lands, are either in the process of approval or waiting for the notarial record, and the " regularized " Indigenous Lands are those which have served every stage of demarcation and have their registration in the real estate registry office and the Secretary of Patrimony of the Union (SPU). Being regularized does not mean that indigenous land does not have conflicts over the territory covered, for instance, in the case of indigenous land Inãwebohoná at Ilha Bananal which is regulated, but the overlap conflicts with the Araguaia National Park are still latent in region. The "Indian Reserve" consists of land donated by others, expropriation or acquired by the Federal Government, not being submitted to the indigenous land demarcation process.

This analysis was made from data obtained from the Indigenous Information System website. From geographical spatial data made available by the National Indian Foundation (FUNAI), the following map was elaborated (Figure 1), to represent the general view of indigenous lands in Brazil, from it you can see the vast quantity of indigenous lands in the north of the country, and a significant demand for land demarcations in the southeastern and southern regions of Brazil, which may represent an ethnic emergency in those areas and the struggle for recognition. 


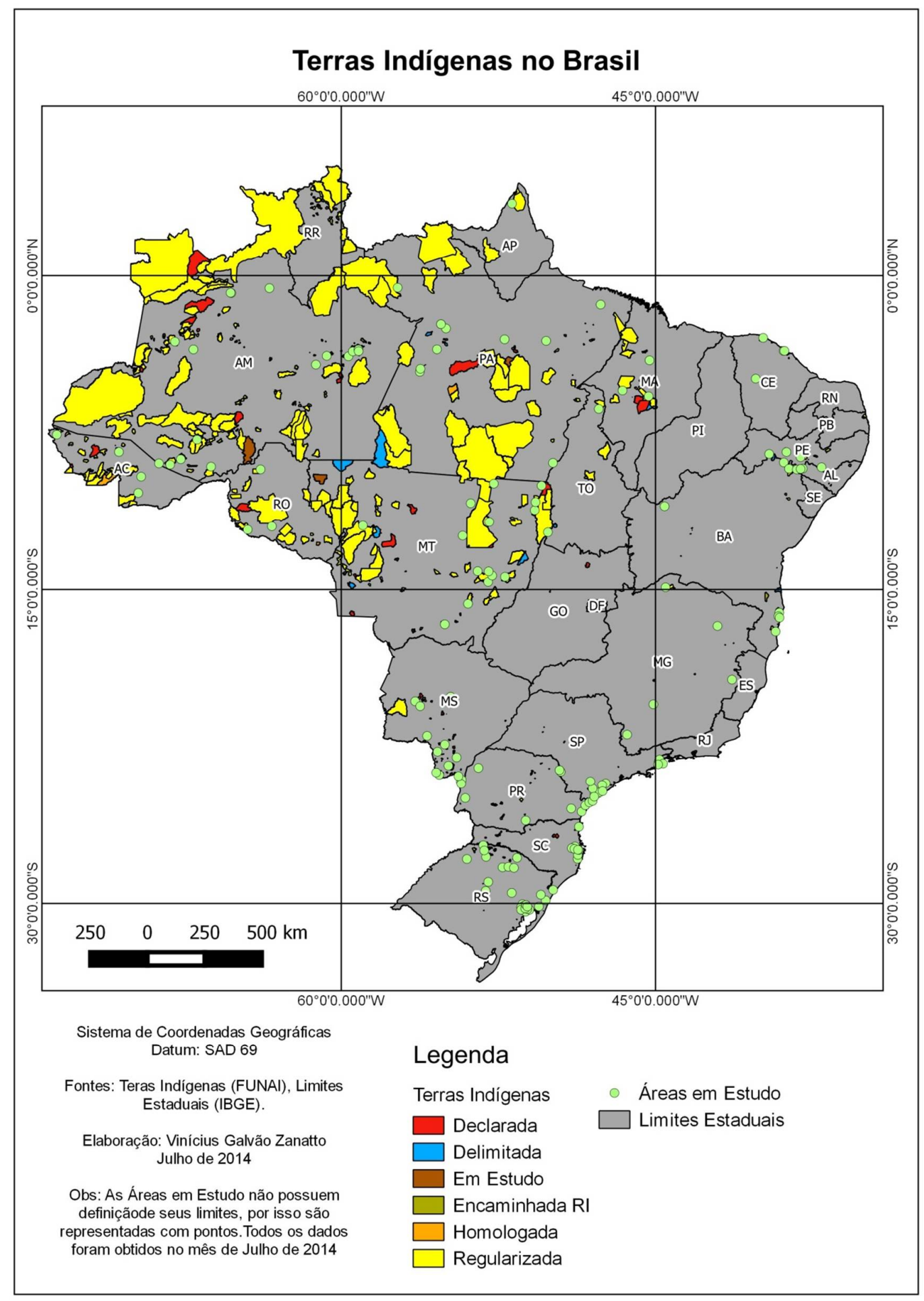

Figure 1: Terras Indígenas no Brasil. Sources: FUNAI and IBGE. Elaborated by: Vinícius Galvão Zanatto, July, 2014. 


\section{DEFINING CONSERVATION UNITS}

According to the National System of Conservation Units, SNUC, which is the legislation concerning the protection of the various biological species, genetic resources, natural resources necessary to support traditional communities, Conservation Units are constituted as:

I - Conservation Unit: territorial space and its environmental resources, including jurisdictional waters, with relevant natural characteristics, legally instituted by the Government, with conservation objectives and defined limits, under special administration regime, to which adequate protection guarantees are applied (ACT $\left.\mathrm{N}^{\circ} .9985,2000\right)$.

Therefore the Conservation Units act as an important tool for the protection of biodiversity, as they will allocate financial, technical and legal resources for the protection of defined geographic areas (SILVA and NOGUEIRA, 2010).

Currently, the Conservation Units are constituted as the main tool for the Brazilian State, responsible for the protection and maintenance of biodiversity and natural resources of the country. The model adopted for the establishment of Conservation Units in Brazil was the Western one that is based on the premise of preserving areas little altered by human beings, of great scenic beauty, the state should also arrange the withdrawal of populations from the area so that there is no more changes in the landscape. Nowadays Conservation Units are created to protect certain species and habitats.

There are currently 320 federal conservation units, with 143 considered to be of integral protection, sustainable use of 177 and 634 Private Reserves of Natural Heritage.

Table 2: Number and UC's area by Category.

\begin{tabular}{|c|c|c|c|c|c|c|c|c|}
\hline \multirow{2}{*}{$\begin{array}{l}\text { Tipo / Categoria } \\
\text { Proteçăo Integral }\end{array}$} & \multicolumn{6}{|c|}{ Esfera } & \multirow{2}{*}{\multicolumn{2}{|c|}{ TOTAL }} \\
\hline & $\mathbf{N}^{\circ}$ & al & $N^{\circ}$ & alal & $N^{\circ}$ & $\begin{array}{l}\text { pal } \\
\text { Área }\left(\mathrm{Km}^{2}\right)\end{array}$ & & \\
\hline Estação Ecológica & 32 & 74.691 & 58 & 47.513 & 1 & 9 & 91 & 122.213 \\
\hline Monumento Natural & 3 & 443 & 28 & 892 & 11 & 73 & 42 & 1.407 \\
\hline Parque Nacional / Estadual / Municipal & 71 & 252.978 & 195 & 94.889 & 95 & 221 & 361 & 348.088 \\
\hline Refúgio de Vida Silvestre & 7 & 2.017 & 24 & 1.729 & 1 & 22 & 32 & 3.768 \\
\hline Reserva Biológica & 30 & 39.034 & 24 & 13.449 & 6 & 48 & 60 & 52.531 \\
\hline Total Proteçäo Integral & 143 & 369.164 & 329 & 158.472 & 114 & 372 & 586 & 528.007 \\
\hline Uso Sustentável & $\mathbf{N}^{\circ}$ & Área $\left(\mathrm{Km}^{2}\right)$ & $\mathbf{N}^{0}$ & Área $\left(\mathrm{Km}^{2}\right)$ & $\mathbf{N}^{\circ}$ & Área $\left(\mathrm{Km}^{2}\right)$ & $\mathbf{N}^{0}$ & Área $\left(\mathrm{Km}^{2}\right)$ \\
\hline Floresta Nacional / Estadual / Municipal & 65 & 163.913 & 39 & 136.053 & 0 & 0 & 104 & 299.966 \\
\hline Reserva Extrativista & 62 & 124.362 & 28 & 20.208 & 0 & 0 & 90 & 144.570 \\
\hline Reserva de Desenvolvimento Sustentável & 2 & 1.026 & 29 & 110.090 & 5 & 176 & 36 & 111.293 \\
\hline Reserva de Fauna & 0 & 0 & 0 & 0 & 0 & 0 & 0 & 0 \\
\hline Area de Proteção Ambiental & 32 & 100.101 & 185 & 334.898 & 77 & 25.922 & 294 & 460.922 \\
\hline Área de Relevante Interesse Ecológico & 16 & 447 & 24 & 443 & 8 & 32 & 48 & 921 \\
\hline RPPN & 634 & 4.832 & 147 & 686 & 1 & 0 & 782 & 5.517 \\
\hline Total Uso Sustentável & 811 & 394.681 & 452 & 602.377 & 91 & 26.131 & 1354 & 1.023 .189 \\
\hline Total Geral & 954 & 763.845 & 781 & 760.848 & 205 & 26.503 & 1940 & 1.551 .196 \\
\hline Área Considerando Sobreposiçăo Mapeada & 954 & 758.733 & 781 & 755.661 & 205 & 26.479 & 1940 & 1.513 .828 \\
\hline
\end{tabular}

Source: Cadastro Nacional de Unidades de Conservação/ Ministério o Meio Ambiente. Updated in February, 2015.

Eletronic M agazine: Time - Techinique - Territorry, V.6, N.1 (2015), 23:43 ISSN: 2177-4366 
The Full Protection Units, according to the National System of Nature Conservation Units, aims to: "§ 1 The basic objective of Full Protection Units is to preserve nature, being only admitted the indirect use of its natural resources, except the cases provided for in this Act. "

The Full Protection Conservation Units do not allow people to live inside the Conservation Unit, thus the units classified as of Sustainable Use, the SNUC deliberates that "§ 2. The basic objective of Sustainable Use Units is to achieve coherence when it comes to nature conservation with the sustainable use of its natural resources portion. "

At the Sustainable Use Units it is allowed the presence of populations inside the unit, as far as compatible with their goals.

Within the Full Protection Units category there are many subdivisions, they are: Ecological Station (ESEC), Biological Reserve (REBIO), National Park (PARNA) Natural Monument (MN) and Wildlife Refuge (REVIS).

The Sustainable Use Units are also divided into several categories, they can be: Environmental Protection Area (APA), Area of Relevant Ecological Interest (ARIE), National Forest (FLONA), Extractive Reserve (RESEX), Fauna Reserve, Sustainable Development Reserve (RDS) and Private Natural Heritage Reserve (RPPN).

By the year 2007 the administration of Federal Conservation Units was attributed to the Brazilian Institute of Environment and Renewable Natural Resources (IBAMA).

In August 2007, through act 11.516, the Chico Mendes Institute for Biodiversity Conservation (ICMBio), which constitutes an autarchy linked to the Ministry of Environment (MMA) was created. ICMBio has as its purpose the proposition, implementation, management, monitoring, enforcement and protection of Federal Conservation Units (act 11 $516,2007)$. The Institute should also promote and implement research programs, protection, preservation and conservation of biodiversity and environmental education in units established by the Union, and has power of environmental police for the protection of Federal Conservation Units (act 11 516, 2007).

Below I will present a map of Federal Conservation Units in Brazil (Figure 2), it is possible to observe how Indigenous Lands the Conservation Units are also located in the northern region of the country and the creation of these is related to the expansion of the agricultural frontier in Brazil. 


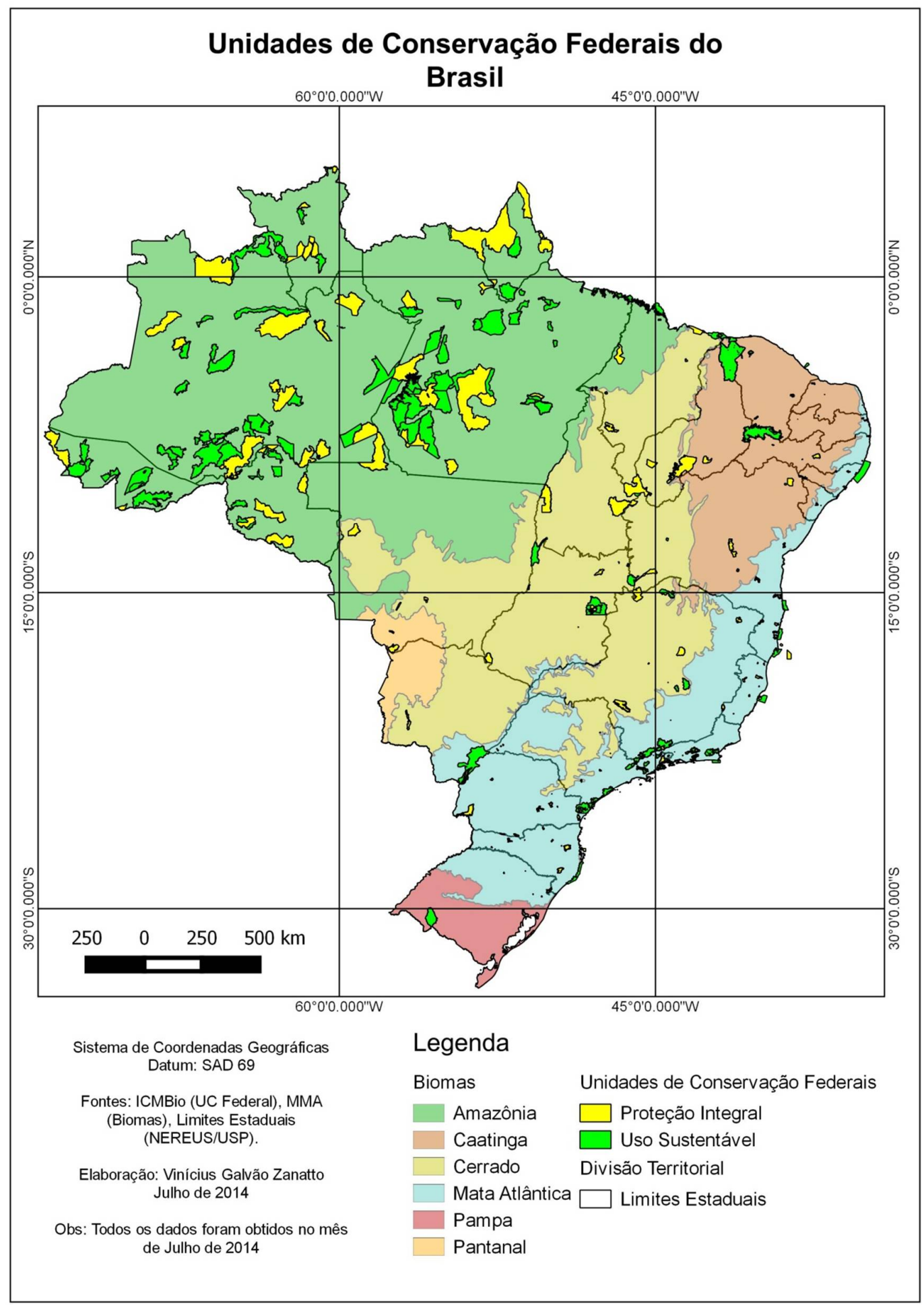

Figure 2: Mapa das Unidades de Conservação do Brasil. Sources ICMBio, MMA, NEREUS/USP, Elaborated by: Vinícius Galvão Zanatto, July, 2014. 


\section{WHY THE OVERLAYS TERRITORIAL DISPUTES ARE NOT RESOLVED? AND WHY SHOULD THEY BE RESOLVED?}

The cases of territorial overlaps are configured in territorial conflicts for being, acknowledgedly, shocking cases of interests over the distinct uses made by the different actors in the territory.

Among the various existing discussions on environmental issues, one that has a lot of interest, relevance and controversy is the compatibility between human presence and biodiversity within the Conservation Units, opinions differ, because there is the idea that human populations with their exploiting nature practices cause damage to the environment, which is incompatible with the existence of Conservation Units, which are usually designed to protect a specific ecosystem or species (Pig, 2004). To Diegues and Arruda (2001), the model of Conservation Units of indirect use, that is, the full protection units arises from the idea that every relationship between society and nature will come to degrade the natural world. The same authors still point out that distinctions between existing societies are not made, and all ways of life should be outside the boundaries of protected areas.

Another bias explored, is that the populations living in Conservation Units, were already there before its creation, and should remain there not only because of the right to use its territory, but are also essential for the maintenance of biodiversity existed therein, as well as the cultural and social reproduction of such traditional and indigenous communities, biodiversity is a fundamental element.

Fany Ricardo (2004) points out that conflicts of territorial overlap are configured to be of more severe forms outside the Amazon region, because the tracts of land are smaller and the surrounding occupation is old and degraded, these populations are more vulnerable, with less conditions to exercise a different culture and also protect the environment encompassing them, because they are targets of squatters and intruders seeking to extract resources from their territories. For these reasons the Conservation Units near indigenous lands stand out as an alternative of enlargement of the territories, as they are less environmentally disfigured, the Indians also recognize such overlap areas as historical occupation that provide conditions for their cultural reproduction.

The Brazilian state has historically never resolved conflicts of territorial overlap. According to Leitão (2004), the problem involving the overlap is understood, by different State structures as a dispute over territory and power, and thus the overlaps are at the mercy of wills and little is done to find solutions that are beneficial to the people involved and the 
environment. The resolution of these conflicts, which can also be considered land conflicts for being territorial disputes, would imply in generating frictions and detritions with politically influential people who are mobilizing to undo actions that do not benefit them (ROCHA, 2002).

Leitão (2004) states that there is negligence on the part of governments to resolve the cases of overlap, and that cases are treated with little seriousness by the public sphere. So serious is the situation that there are several cases in which Conservation Units were created on previously established indigenous lands, and there are cases that also, such as the Ecological Station of Iquê, where the Indigenous land Enawene Nawe was demarcated after the Conservation Unit, the fact generated conflict, because those who support the indigenous lands to rely on the constitutional right established that states that the acts which have as their object the occupation, use or possession of indigenous lands become null or canceled, but the environmentalist current arises against this argument pointing out that protected areas can only be extinguished by Law voted on and passed by Congress, and that the Constitution guarantees everyone the right to a balanced ecological environment.

The non-resolution of conflicts involving indigenous lands and Conservation Units, masks the great pressures on land and resources taken by the agribusiness, by mining exploration, logging and large enterprises.

Indigenous Lands were ignored when it came to formulate an environmental policy, which should not have occurred, because the extent of land covered by indigenous lands exceeds the protected areas. The National System of Conservation Units (SNUC), only one mention of indigenous lands is made which is exactly the overlap between indigenous lands and Conservation Units:

Art. 57. Federal agencies responsible for implementing environmental policies and indigenous shall set up working groups to, within one hundred and eighty days from the effective date of this Act, propose guidelines to be adopted with a view to settlement of any overlapping between indigenous lands and protected areas. (ACT No. 9985, 2000).

Indigenous peoples are fundamental actors for building an efficient environmental policy, as Indigenous lands occupy more than 100 million ha, about $13 \%$ of the country.

Nurit Bensusan points out that indigenous lands feature a variety of ecosystems and that they present relative preservation of natural resources and therefore should be covered in the environmental protection policies. Indigenous peoples living with natural ecosystems for a 
long time and such policies could also benefit indigenous peoples, therefore, in order to maintain their traditions, cultures and social organizations a balanced environment is required.

It is a fact that indigenous lands contribute to the protection and maintenance of biodiversity and natural resources, as in most of the areas they are part of a mosaic of protected areas that prevent the advance of deforestation (SANTILLI, 2010). This characteristic can be seen in Figures 3 and 4, which first shows, as a whole, these protected areas complexes forming large ecological corridors that prevents the fragmentation of ecosystems, and more specifically the TI Parakanã, in the state Pará, which contains surrounding deforestation and occupation. Based on the TI Parakanã map (Figure 4) we can see that this one is isolated, what according to the biodiversity point of view is negative because there is no gene flow between species, not to mention the many conflicts that can be generated from the proximity of these remaining areas with areas of urban expansion and agricultural production because of the different uses of the territory, such as the invasion of wild animals in areas of agricultural production. Then there is a need to create a neutral zone and connect it with other protected areas, so that these conflicts are minimized, it would be positive both for farmers and for indigenous communities and biodiversity in general. 


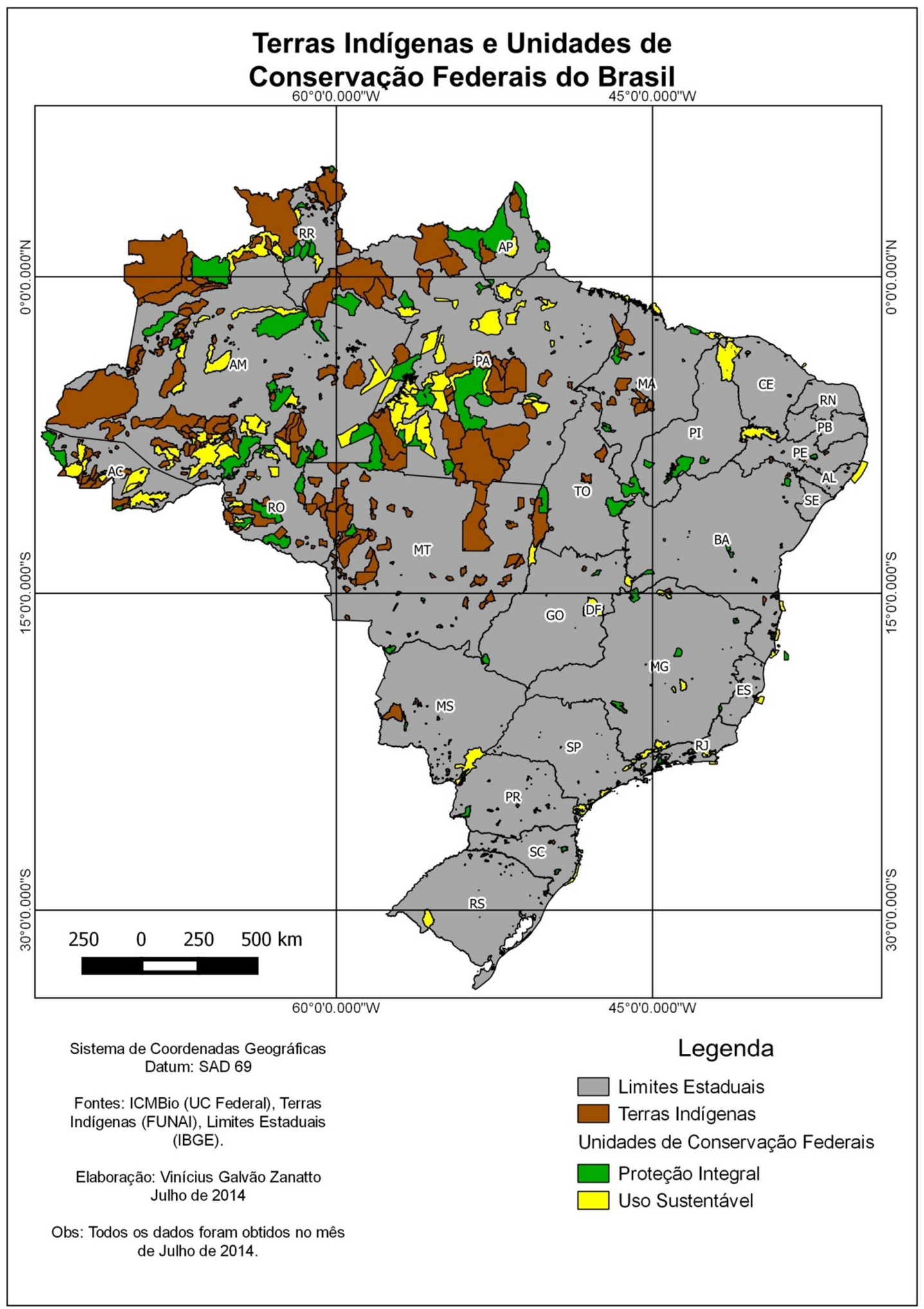

Figure 3: Mapa Terras Indígenas e Unidades de Conservação Federais do Brasil.Sources: ICMBio, FUNAI e IBGE. Elaborated by: Vinícius Galvão Zanatto, July, 2014. 


\section{TI Parakanã Impedindo o Avanço do desmatamento}

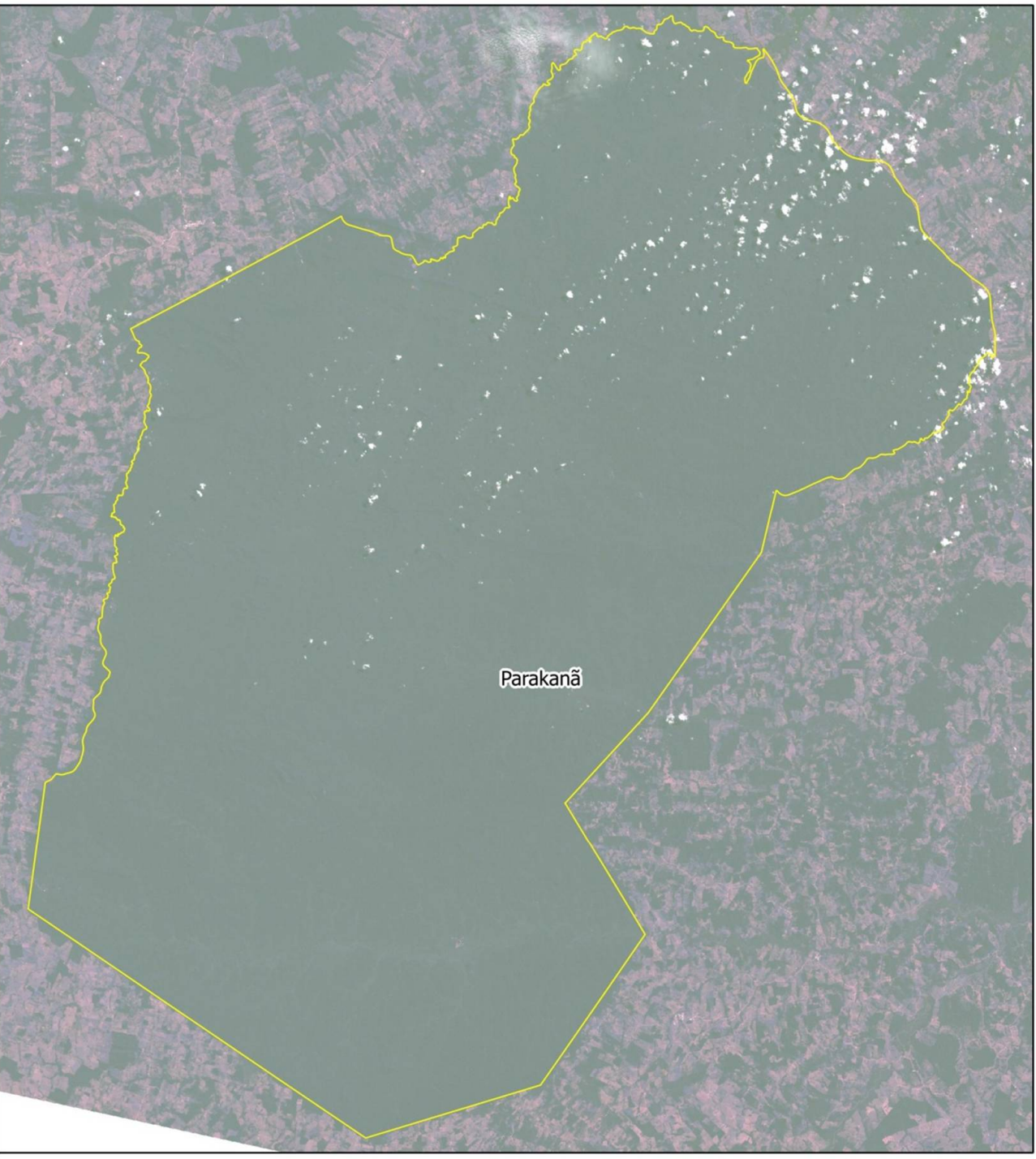

Sistema de Coordenadas Geográficas Datum Sirgas 2000

Fontes: Terra Indígena (FUNAI), Imagem Landsat 8 (Serviço Geológico Americano)
Elaboração: Vinícius Galvão Zanatto

Obs: Imagem de Agosto de 2013. Composição das Bandas 4/3/2

\section{Legenda}

Terra Indígena

Área Preservada

Área Antropizada

Figure 4: Mapa TI Parakanã Impedindo o Avanço do Desmatamento.Sources: FUNAI and USGS. Elaborated by: Vinícius Galvão Zanatto, October, 2014. 
The Overlays occur in areas of strong endemism and also in the transition areas between the Cerrado and Amazon biomes, so the knowledge that indigenous peoples have about biodiversity serve as a reference for science (SANTILLI, 2010).

From a demand of the indigenous movement and taking into account the potential of indigenous lands for environmental preservation and the great external pressure suffered by indigenous territories, it is being implemented since 2008, the National Policy for Environmental and Territorial Management on Indigenous Land (PNGATI), which aims to:

Ensure and promote the protection, restoration, conservation and sustainable use of natural resources in indigenous lands and territories, ensuring the integrity of indigenous heritage, improving the quality of life and full conditions of physical and cultural reproduction of current and future generations of indigenous peoples, respecting their socio-cultural autonomy, under current legislation. (Decree No. 7747, OF 5 JUNE 2012).

The PNGATI has shown to be innovative in the sense that it proposes indigenous participation and role in the formation of a new Indigenous Policy and brings it to the discussion of environmental issues, and the Ministry of Environment and ICMBio participation in the construction of this policy. Thus minimizing the problems arising from the State's failure at the time formulated an environmental policy without considering the indigenous peoples.

If we add the total area of Indigenous Lands and Federal Protected Areas, State and Municipal we will have an area of 210 million ha of protected areas, each with its specific characteristics having enormous potential for biodiversity conservation and the reduction of social inequalities, if the rights of people living in such areas are respected.

\section{CONCLUSION}

From the key statements made during this work I observed the necessity for a plan that aims at environmental and territorial management of indigenous lands in Brazil, because from the knowledge of the uses made of the territory, it is possible to propose actions that minimize environmental impacts and reduce social inequalities, thus preserving the traditional indigenous culture and the environment of the regions. In this sense PNGATI is a useful tool, but it is not showing itself to be fully efficient and in accordance with the needs of the communities involved.

Yet from the perspective of planning it is necessary that revisions to the plans of management of protected areas affected by overlaps to be made, in order to consider 
indigenous communities and include them in the construction of this material, since the communities are the greatest ones interested in maintaining natural resources because they are the ones who feel the most severe environmental impacts generated from human action.

There is a need to work for the integrated management of the territory, since the protected areas alone are not able to preserve the long-term biodiversity because those are fragmented areas that do not permit gene flow between species, and the establishment of mosaics and ecological corridors can promote the conservation of natural resources, traditional cultures, both indigenous and others like maroons and extractive communities. Such actions can reduce the contradictions between protected areas and their immediate surroundings, thus reducing inequality in the territory (GANEM, 2011).

The conflicts that arise from the territorial overlap between Conservation and Indigenous Land units can be reversed if there is potential for greater dialogue between environmental agencies and indigenous, since the potential for preservation of indigenous lands is evident.

The indiscriminate use of natural resources and the precarious situation of indigenous communities can only be reversed if there is a joint action of the organs, but you can observe that environmental agencies and indigenous were placed in conflicting situations, as if very distant proposals from each other but the reality is not such as to the indigenous communities to continue keeping their traditions, we need a balanced environment, and their knowledge of biodiversity may be appropriate for science to permit a sustainable management of this biodiversity, so there is a dialogue between scientific knowledge and traditional knowledge.

The discussion on the environmental issue is relevant, since our society has exhausted natural resources, but should never be discussed the right of residence of indigenous peoples in their territories, if today we still see a great diversity of plant and animal species in the Indian territories, it is because these people are there, and the pressure suffered by them is caused by our society, which puts them now as squatters on their own land.

The question of the right to remain or not in the land, if the indigenous and traditional communities are good or not for biodiversity, only masks the real problem as the major threat to both indigenous peoples and the environment does not occur with overlaps between Conservation Units and Indigenous Lands, but the established development model and stimulated by the state.

We can see the threats to indigenous peoples and the environment, when we see the projects being discussed by our parliamentarians, the PEC 215 for instance is a clear example 
as it aims to remove the power of demarcation of indigenous lands from Executive branch, in the case of FUNAI, and leave it to the Legislature, another point that demonstrates the attacks on the environment was the reformulation of the Brazilian Forest Code. We can see that the interests at stake are not those of the general population, these are actually the interests of those who finance election campaigns.

We must bear in mind which Brazil we are building, which is the national project we want, we have to take into account our ethnic, multicultural and multiracial, our biological diversity and the most diverse knowledge that are scattered amongst the states, regions and biomes. Only when we have this notion of this situation of ours, we will be able to build a more just society.

\section{BIBLIOGRAPHICAL REFERENCE}

BECKER, Berta Koiffmann, Amazônia: geopolítica na virada do terceiro milênio, Rio de Janeiro, Editora Garamond, 2004.

BENSUSAN, Nurit. Conservação da Biodiversidade e Presença Humana: é possível conciliar? Disponível

em <http://www.funai.gov.br/ultimas/e_revista/artigos/biodiversidade_nurit.pdf > acesso em 2 de fevereiro de 2014.

BRASIL, Constituição da República Federativa do Brasil, Brasília, DF, Senado Federal, 1988.

BRASIL, Lei de $\mathbf{N}^{\mathbf{0}}$ 9.985, de 18 de julho de 2000, Regulamenta o art. 225, $\S 1^{\circ}$, incisos I, II, III e VII da Constituição Federal, institui o Sistema Nacional de Unidades de Conservação da Natureza e dá outras providências, disponível em <http://www.mma.gov.br/estruturas/240/_arquivos/snuc_240.pdf> acesso em: 23 de novembro de 2013.

BRASIL, Lei de $\mathrm{N}^{\circ}$ 11.516, de 28 de agosto de 2007, Dispõe sobre a criação do Instituto Chico Mendes de Conservação da Biodiversidade - Instituto Chico Mendes, disponível em < http://www.planalto.gov.br/ccivil_03/_ato2007-2010/2007/lei/111516.htm> acesso em: 20 de junho de 2015.

CLAVAL, Paul, A Geografia Cultural, Florianópolis, Editora da Universidade Federal de Santa Catarina, 1999 (1995). 
DIEGUES, Antônio Carlos, Arruda, Rinaldo S. V, Saberes tradicionais e biodiversidade no Brasil, Brasília, Ministério do Meio Ambiente, São Paulo, USP, 2001.

GALLOIS, Dominique Tilkin, Terras ocupadas? Territórios? Territorialidades? In: Fany Ricardo (org.) “Terras Indígenas \& Unidades de Conservação da natureza: o desafio das sobreposições”. São Paulo, Instituto Socioambiental, 2004.

GANEM, Roseli Senna, Gestão Integrada da Biodiversidade: corredores, mosaicos e resevas da biosfera, In: Ganem, Roseli Senna (org) "Conservação da Biodiversidade: legislação e políticas públicas, Brasília, Câmara dos Deputados, Edições Câmara, 2011.

HAESBAERT, Rogério. Des-caminhos e perspectivas do território, In Ribas, D. Sposito, E, S. Saquet, M, A. (orgs) "Território e Desenvolvimento: diferentes abordagens". Francisco Beltrão, Unioeste, 2004.

LEITÃO, Sérgio, Superposição de leis e de vontades: Por que não se resolve o conflito entre Terras Indígenas e Unidades de Conservação? In: Fany Ricardo (org.) “Terras Indígenas \& Unidades de Conservação da natureza: o desafio das sobreposições”. São Paulo, Instituto Socioambiental, 2004.

LIMA, Sélvia Carneiro de, Povo indígena do cerrado goiano: os Karajá de Aruanã, In: Pelá, Márcia; Castilho, Denis. (org.), “Cerrados: perspectivas e olhares”. Goiânia, Editora Vieira, 2010.

LITTLE, Paul E. Territórios sociais e povos tradicionais no Brasil: por uma antropologia da territorialidade. Brasília: Universidade de Brasília, 2002. Série Antropologia $\mathrm{n}^{\circ}$ 322.<Disponível em http://www.direito.caop.mp.pr.gov.br/arquivos/File/PaulLittle__.pdf>. Acesso em: 13 de fevereiro de 2014.

RICARDO, Fany, Terras Indígenas \& Unidades de Conservação da natureza: o desafio das sobreposições. São Paulo, Instituto Socioambiental, 2004.

ROCHA, Leonardo G.M da, Desmistificando a questão fundiária dos parques nacionais brasileiros, In: "III Congresso Brasileiro de Unidades de Conservação”, anais, Fortaleza, Rede Nacional Pró-Unidades de Conservação, Fundação o Boticário de Proteção à Natureza, Associação Caatinga, 2002. 
SANTOS, Milton, Por Uma Outra Globalização: do pensamento único à consciência universal, São Paulo, Editora Record, 2002.

SANTILLI, Márcio, Terras Indígenas e Crise Climática, In: Valle, Raul Silva Telles do. (org.) "Desmatamento Evitado (REDD) e Povos Indígenas: Experiências, Desafios, e Oportunidades no Contexto Amazônico". São Paulo, Instituto Socioambiental e Forest Trends, 2010.

SAQUET, Marcos Aurélio, O território: diferentes interpretações na literatura italiana, In Ribas, D. Sposito, E, S. Saquet, M, A. (orgs) “Território e Desenvolvimento: diferentes abordagens”. Francisco Beltrão, Unioeste, 2004.

SILVA, Marilene Alves da, NOGUEIRA, Ricardo José Batista, Sobreposição de Territórios: Unidades de Conservação e Terras Indígenas no Médio Solimões, In: Anais XVI Encontro Nacional dos geógrafos, Porto Alegre, 2010.

VILELA, Rodrigo de Oliveira, Quilombos Contemporâneos e a proteção da Biodiversidade: $\mathrm{O}$ caso da Reserva biológica da Mata Escura e da Comunidade Mumbuca. Vale do Jequitinhonha/MG, Brasília, Universidade de Brasília, 2013.

ZANATTO, Vinícius Galvão, Conflitos Institucionais em Territórios Indígenas: o caso das terras indígenas da Ilha do Bananal e o Parque Nacional do Araguaia - TO, Brasília, Universidade de Brasília, 2014. 